\title{
Degradation Kinetics of Catechin in Aqueous Solution in the Presence of Ascorbic Acid or Octanoyl Ascorbate
}

\author{
Yoshiyuki WATANABE ${ }^{1, \dagger}$, Tatsunori OKAYASU ${ }^{1}$, Kana IDENOUE ${ }^{1}$ \\ and Shuji ADACHI ${ }^{2}$ \\ ${ }^{1}$ Department of Biotechnology and Chemistry, School of Engineering, Kinki University, \\ 1 Umenobe, Takaya, Higashi-Hiroshima 739-2116, Japan, \\ ${ }^{2}$ Division of Food Science and Biotechnology, Graduate School of Agriculture, Kyoto University, \\ Sakyo-ku, Kyoto 606-8502, Japan
}

\begin{abstract}
The amphilic antioxidant, such as acyl ascorbate, would be expected to be a useful food additive. In this study, the antioxidative action of acyl ascorbate was examined, because knowledge of its behavior in aqueous solution is required for its effective use for food. First, the degradation kinetics of $(+)$-catechin in aqueous solution at various $\mathrm{pHs}$ and temperatures were empirically expressed by the Weibull equation. The rate constant, $k$, was the lower at the lower $\mathrm{pH}$ and temperature. The temperature-dependency of the $k$ value was analyzed on the basis of the Arrhenius equation, and it was indicated that the enthalpy-entropy compensation held during the degradation. Second, octanoyl L-ascorbate was synthesized by the condensation of L-ascorbic and octanoic acids in acetone using immobilized lipase from Candida antarctica, and the degradation kinetics of catechin in aqueous solution in the presence of octanoyl ascorbate was examined. The dependency of the $k$ value in the catechin solution with octanoyl ascorbate on the concentration of the ascorbate was obviously different from that with ascorbic acid. That is, the degradation was suppressed at low octanoyl ascorbate concentrations, while proceeded fast at a high concentration, suggesting the formation of the micelle for octanoyl ascorbate at high concentrations.
\end{abstract}

Key words: Catechin, degradation kinetics, ascorbic acid, octanoyl ascorbate, micelle formation

\section{Introduction}

$\mathrm{L}$-Ascorbic acid is a water-soluble vitamin known as vitamin $\mathrm{C}$, and widely used as an additive in foods and cosmetics due to its strong reducing ability. The lipasecatalyzed synthesis of $6-O-$ acyl ascorbate through the condensation of ascorbic acid and fatty acid in an organic solvent has been reported [1,2]. The enzymatic synthesis of the acyl ascorbates would be more advantageous than a chemical method due to the simplicity of its reaction process and its high regioselectivity. Acyl ascorbate is an amphilic antioxidant, as it consists of ascorbic acid and a fatty acid as the hydrophilic antioxidant and lipophilic group, respectively. It has been reported that the ascorbates, such as $6-\mathrm{O}^{-}$-palmitoyl ascorbate, have an antitumor activity and metastasis-inhibitory effects [3,4]. Therefore, acyl ascorbate would be expected to be a use-

(Received 31 May. 2009: accepted 4 Jun. 2009)

$\dagger$ Fax: 082-434-7890, E-mail: wysyk@hiro.kindai.ac.jp ful food additive. We have also synthesized acyl ascorbates using an immobilized lipase in a batch or continuous reactor [5,6], evaluated their surfactant properties [7] and their antioxidative ability against linoleic acid [8], and used them for the microencapsulation of lipids [9]. However, there has been no report about the antioxidative property of acyl ascorbate against a water-soluble and unstable compound in aqueous solution, though knowledge of its behavior in aqueous solution is required for its effective use.

Catechins are recognized as constituents of green tea with an antioxidative activity [10] and suppressive ability against adipocyte differentiation [11]. Most tea drinks containing catechins are low acid beverages, and kept warm in the vending system during the cold season. Furthermore, heat processing at high temperature is required to sterilize the spores of thermophilic anaerobes. Thus, the stability of tea catechins in aqueous solution has been investigated under various conditions by many researchers [12,13], and the degradation is kinetically examined using first-order kinetics [14,15]. 
In this study, the degradation of $(+)$-catechin in aqueous solution at various $\mathrm{pHs}$ and temperatures were determined. The degradation was expressed by the probabilistic Weibull equation and the kinetic parameters were evaluated. Octanoyl ascorbate, which is a hydrophilic surfactant, was synthesized using an immobilized lipase by the condensation of ascorbic and octanoic acids in acetone. The degradation kinetics of catechin in an aqueous solution in the presence of either ascorbic acid or octanoyl ascorbate was also examined.

\section{Materials and Methods}

\subsection{Materials}

(+)-Catechin (purity: 98\%) was purchased from Sigma (St. Louis). Caffeine, which was used as the internal standard for the determination of catechin by HPLC, was purchased from Kishida Chemical (Osaka). L(+)-Ascorbic acid and octanoic acid were purchased from Nacalai Tesque (Kyoto), and Wako Pure Chemical Industries (Osaka), respectively. All other chemicals of analytical grade were purchased from Wako and Yoneyama Chemical (Osaka).

Octanoyl L-ascorbate was synthesized by the condensation of ascorbic and octanoic acids in acetone using immobilized lipase, Chirazyme ${ }^{\circledR} \mathrm{L}-2 \mathrm{C} 2$, from Candida antarctica fraction B (Roche Molecular Biochemicals (Mannheim)) and purified according to previous methods [2].

\subsection{Degradation of catechin under various conditions}

Catechin was dissolved in $0.2 \mathrm{~mol} / \mathrm{L}$ sodium phosphate buffer, $\mathrm{pH} 6.5$, to produce $10 \mathrm{mmol} / \mathrm{L}$. The catechin solution was diluted with the buffer to prepare the catechin solutions of 1.0 and $2.5 \mathrm{mmol} / \mathrm{L}$. Each solution $(10 \mathrm{~mL})$ was put in an amber vial and the vial was kept at $37^{\circ} \mathrm{C}$ in a thermostated water bath. At appropriate intervals, a portion of the solution $(50 \mu \mathrm{L})$ was removed from the vial, and mixed with $50 \mu \mathrm{L}$ of $1.3 \mathrm{mmol} / \mathrm{L}$ caffeine and $900 \mu \mathrm{L}$ of the eluent for HPLC analysis. The mixture $(20 \mu \mathrm{L})$ was applied to a Chemcosorb300-5C18 column $\left(4.6 \mathrm{~mm}^{\phi} \times\right.$ $250 \mathrm{~mm}$; Chemco Scientific, Osaka) and eluted with a mixture of methanol, water and phosphoric acid (20/80/0.5 by vol.) at $1.0 \mathrm{~mL} / \mathrm{min}$ using a Shimadzu LC-10AT pump (Kyoto). The elution profiles of the catechin and caffeine were monitored using a Shimadzu SPD-10A UV detector at $280 \mathrm{~nm}$.

One mmol/L catechin solutions were prepared by dis- solving it with $0.2 \mathrm{~mol} / \mathrm{L}$ sodium phosphate buffers of $\mathrm{pH}$ $5.0,6.0,6.5,7.0$ and 7.5 . These pHs were selected, because most tea drinks containing catechin were low acid beverages. The solutions were kept at $37^{\circ} \mathrm{C}, 50^{\circ} \mathrm{C}$, $60^{\circ} \mathrm{C}$ or $70^{\circ} \mathrm{C}$, and the concentrations of the remaining catechin were determined by the above-mentioned procedures. Temperature was, for convenience, selected to obtain the results within short time.

\subsection{Degradation of catechin in the presence of ascorbic acid or octanoyl ascorbate}

Ascorbic acid or octanoyl ascorbate was dissolved in $0.2 \mathrm{~mol} / \mathrm{L}$ sodium phosphate buffer, $\mathrm{pH} 6.0$, to obtain each solution at the concentration of $10 \mathrm{mmol} / \mathrm{L}$. Each solution was mixed with $10 \mathrm{mmol} / \mathrm{L}$ catechin solution at the appropriate volume. The concentration of ascorbic acid or octanoyl ascorbate was from 0.001 to $5 \mathrm{mmol} / \mathrm{L}$, and that of catechin was $1.0 \mathrm{mmol} / \mathrm{L}$. Ten milliliters of each mixture was put in an amber vial and the vial was immersed in a water bath at $60^{\circ} \mathrm{C}$. The catechin solution with octanoyl ascorbate was kept at various temperatures from $37^{\circ} \mathrm{C}$ to $70^{\circ} \mathrm{C}$. The sampling and HPLC analysis were carried out by the above methods.

\subsection{Partition coefficient of catechin \\ between methyl octanoate and water}

The catechin solution dissolved in $0.2 \mathrm{~mol} / \mathrm{L}$ sodium phosphate buffer, $\mathrm{pH} 6.5$, was prepared at the concentrations of $0.1,1$ and $10 \mathrm{mmol} / \mathrm{L}$, which were the initial concentrations, $C_{\mathrm{aq}, 0}$, in the water phase. Five milliliters of the catechin solution and methyl octanoate as the organic phase were mixed in an amber vial. The vial was immersed in a water bath at $37^{\circ} \mathrm{C}$, then vigorously shaken for $1 \mathrm{~h}$. Fifty microliters of the water phase in the mixture was removed, and the concentration of catechin in the water phase at the partition equilibrium, $C_{\mathrm{aq}}$, was measured by the above-mentioned HPLC analysis.

The mass balance for the partition of catechin between methyl octanoate and water is expressed by the following equation:

$$
C_{\text {aq, } 0} V_{\text {aq }}=C_{\text {aq }} V_{\text {aq }}+C_{\text {org }} V_{\text {org }}
$$

where $V_{\text {aq }}$ and $V_{\text {org }}$ are the volumes in the water and organic phase, respectively, and $C_{\text {org }}$ is the concentration of catechin in the organic phase at the partition equilibrium. Equation (1) is converted to Eqn. (2), and $C_{\text {org }}$ is calculated from the measured $C_{\mathrm{aq}}$.

$$
C_{\text {org }}=\left(C_{\text {aq, } 0}-C_{\text {aq }}\right) V_{\text {aq }} / V_{\text {org }}
$$


The partition coefficient, $P$, of catechin between methyl octanoate and water is defined as Eqn. (3).

$$
P=C_{\mathrm{org}} / C_{\mathrm{aq}}
$$

The measurement of the partition coefficient was done in duplicates, and the mean value was calculated.

\section{Results and Discussion}

\subsection{Degradation of catechin at different concentrations}

Figure 1 shows the transient changes in the fractions of remaining catechin, $C / C_{0}$, at the initial concentration of $1.0,2.5$ and $10 \mathrm{mmol} / \mathrm{L}$ in an aqueous solution at $37^{\circ} \mathrm{C}$ and $\mathrm{pH}$ 6.5. $C_{0}$ and $C$ represent the initial concentration of catechin and that at time, $t$, respectively. The fraction was greater than 0.5 after 6 days at each concentration. The degradation kinetics of the catechin was empirically expressed by the Weibull equation, which is flexible and can be use to describe many deterioration kinetics [16]:

$$
C / C_{0}=\exp \left[-(k t)^{n}\right]
$$

where $k$ is the rate constant, the reverse of which is called the scale parameter, and $n$ is the shape constant. The kinetic parameters, $k$ and $n$, were evaluated by fitting the experimental results by a nonlinear regression using Solver of Microsoft ${ }^{\circledR}$ Excel 2003. The curves in Fig. 1 were drawn based on the equation using the estimated

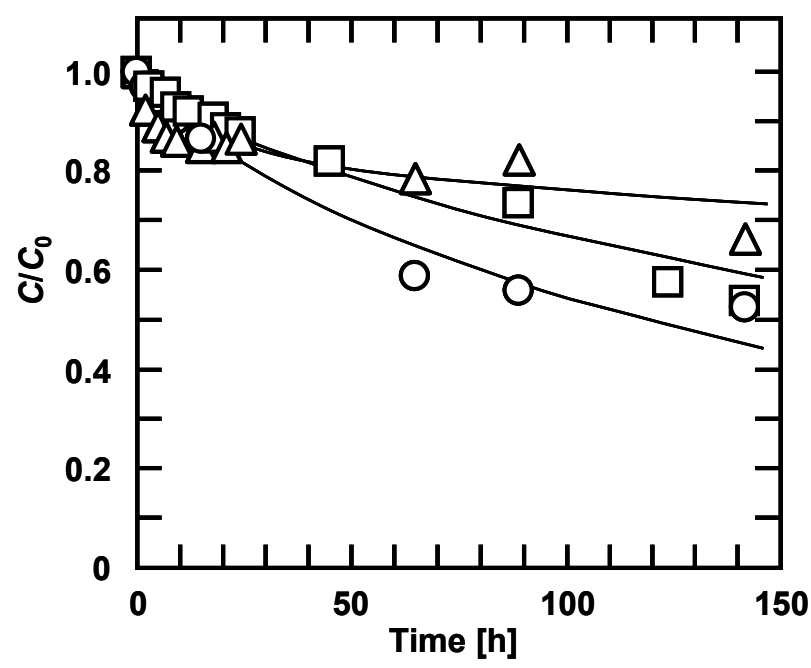

Fig. 1 The transient changes in the fractions of remaining catechin at the concentration of $(\bigcirc)$ 1.0, $(\square) 2.5$ and $(\triangle)$ $10 \mathrm{mmol} / \mathrm{L}$ in an aqueous solution at $37^{\circ} \mathrm{C}$ and $\mathrm{pH}$ 6.5. The solid curves were calculated using the estimated kinetic parameters of the Weibull model. parameters. The $R$-squares for $1.0,2.5$ and $10 \mathrm{mmol} / \mathrm{L}$ of catechin were $0.990,0.981$ and 0.838 , respectively. Figure 2 shows the relationships between the rate constant or the shape constant of the Weibull model for the degradation of catechin and its concentration at $37^{\circ} \mathrm{C}$ and $\mathrm{pH}$ 6.5. Both the $k$ and $n$ values decreased with the increase in the initial concentration, and especially the values were low at the concentration of $10 \mathrm{mmol} / \mathrm{L}$. However, the goodness of fit of the Weibull model for the degradation of $10 \mathrm{mmol} / \mathrm{L}$ catechin was low. The $n$ value for each concentration was less than 1 , which indicated that the fraction of remaining catechin rapidly decreased during the early stage of storage and its decrease gradually became smaller. These results showed that the fraction of remaining catechin more slowly decreased at the higher initial concentration. The degradation process of catechin was thereafter measured at the concentration of 1.0 $\mathrm{mmol} / \mathrm{L}$.

\subsection{Effects of $\mathrm{pH}$ and temperature on the degradation of catechin}

Figure 3 shows the degradation processes of catechin at 37, 50, 60 and $70^{\circ} \mathrm{C}$ and $\mathrm{pH} 5.0,6.0,6.5,7.0$ and 7.5. The degradation of catechin proceeded fast at high temperature and $\mathrm{pH}$ in the aqueous solution. These trends were same as the previous reports [12,14]. Each degradation process was fully expressed by the Weibull model. Figure 4 shows the temperature dependencies of the $k$

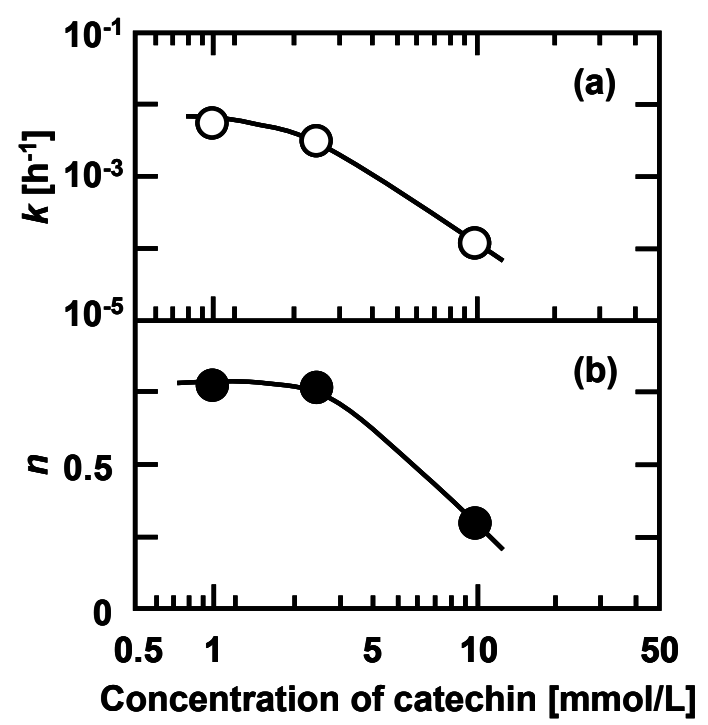

Fig. 2 Relationships between (a) the rate constant, $k$, or (b) the shape constant, $n$, of the Weibull model for the degradation of catechin and its concentration at $37^{\circ} \mathrm{C}$ and $\mathrm{pH}$ 6.5. The solid curves were empirically drawn. 


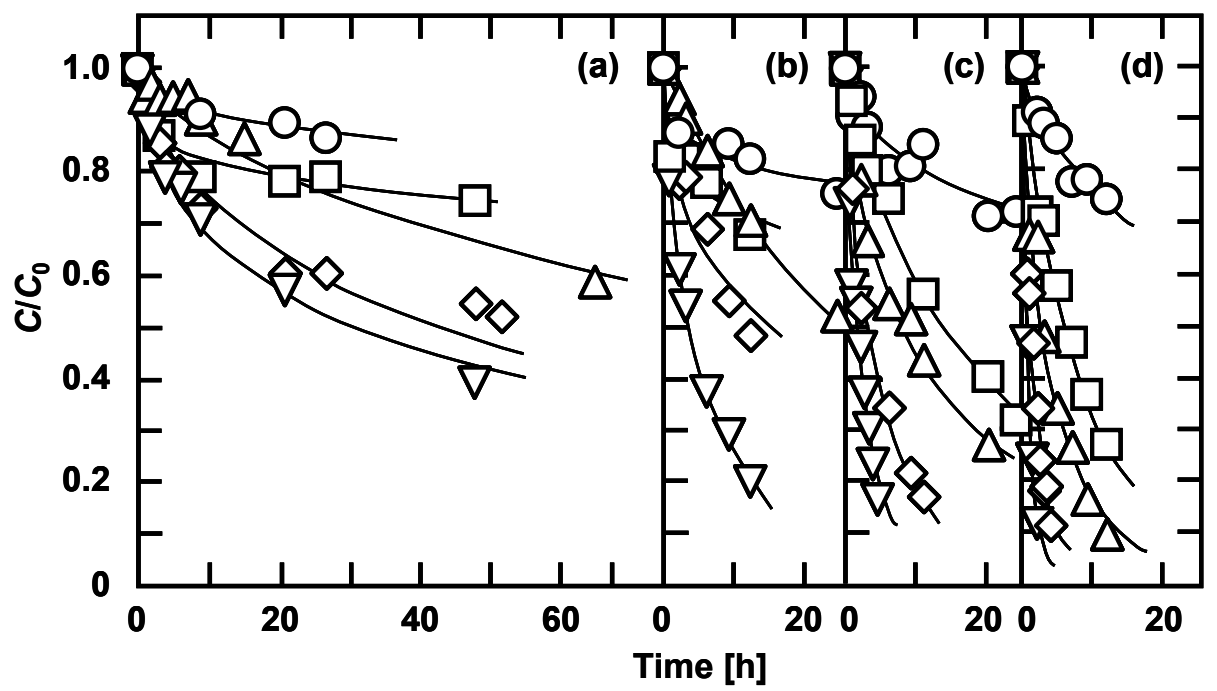

Fig. 3 Degradation processes of catechin at (a) $37^{\circ} \mathrm{C}$, (b) $50^{\circ} \mathrm{C}$, (c) $60^{\circ} \mathrm{C}$ and (d) $70^{\circ} \mathrm{C}$ and $(\bigcirc)$ $\mathrm{pH} 5.0,(\square) \mathrm{pH} 6.0,(\triangle) \mathrm{pH} 6.5,(\diamond) \mathrm{pH} 7.0$ and $(\nabla) \mathrm{pH} 7.5$. The solid curves were calculated using the estimated kinetic parameters of the Weibull model.

and $n$ values for the degradation of catechin at various pHs. The $k$ value was higher at the higher temperatures. The Weibull model has characteristics of a sigmoidal pattern that can be described when $n>1$, that the model expresses the simple first-order kinetics at $n=1$, and

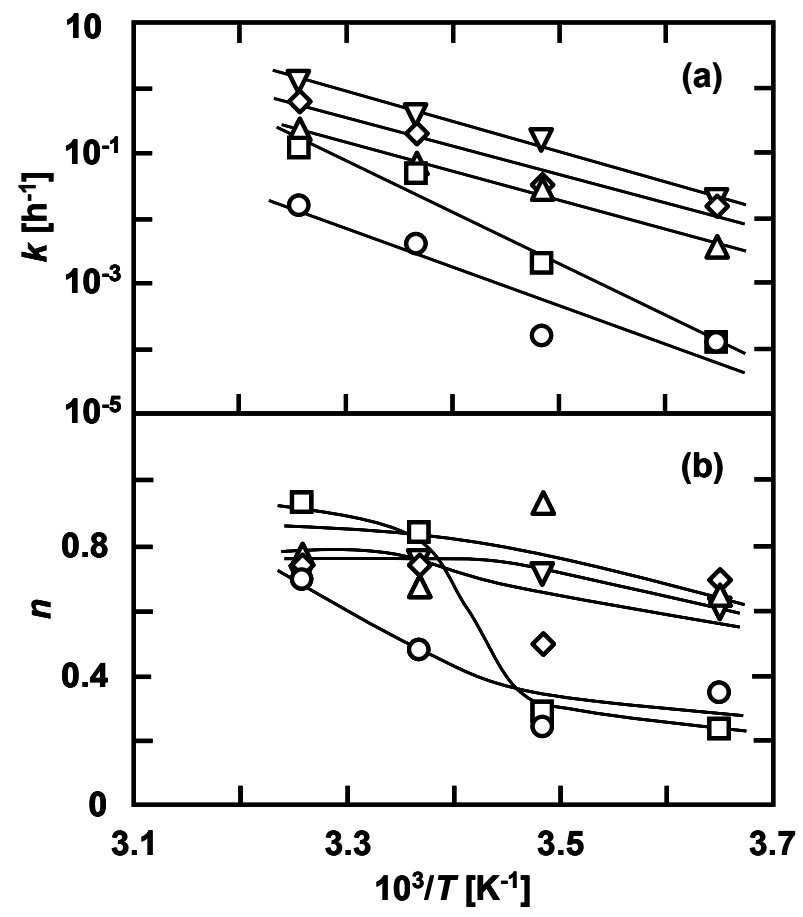

Fig. 4 Temperature dependencies of (a) the rate constants, $k$, and (b) the shape constants, $n$, of the Weibull model for the degradation of catechin. The symbols are the same as in Fig. 3. The solid curves were empirically drawn. that $C / C_{0}$ steeply decreases during the early stage when $n<1$. All the $n$ values at tested pHs were smaller than unity. There was no remarkable tendency for the $n$ value at every $\mathrm{pH}$, but the $n$ value seemed to decrease with increasing temperature.

The temperature dependence of the rate constant $k$ was analyzed based on the Arrhenius equation:

$$
k=k_{0} \exp (-\mathrm{E} / R \mathrm{~T})
$$

where $k_{0}$ is the frequency factor, $E$ is the apparent activation energy, $R$ is the gas constant, and $T$ is the absolute temperature. The Arrhenius plots in Fig. 4(a) produced a straight line to evaluate the $E$ and $k_{0}$ values from the slope and the intercept of the line, respectively. It would be expected that the enthalpy-entropy compensation held during the decomposition. Equation 6 is one of the expressions describing the compensation [17-19].

$$
E=R T_{\beta} \ln k_{0}+\gamma
$$

where $T_{\beta}$ is an isokinetic temperature and $\gamma$ is a constant. The $E$ values are plotted versus the logarithms of the $k_{0}$ values in Fig. 5 . The plots lie on a straight line $\left(R^{2}\right.$ $=0.978$ ), suggesting that each degradation of catechin at the various pHs essentially proceeded by the same mechanism. The $T_{\beta}$ value was estimated to be $46.4^{\circ} \mathrm{C}$ from the slope. 


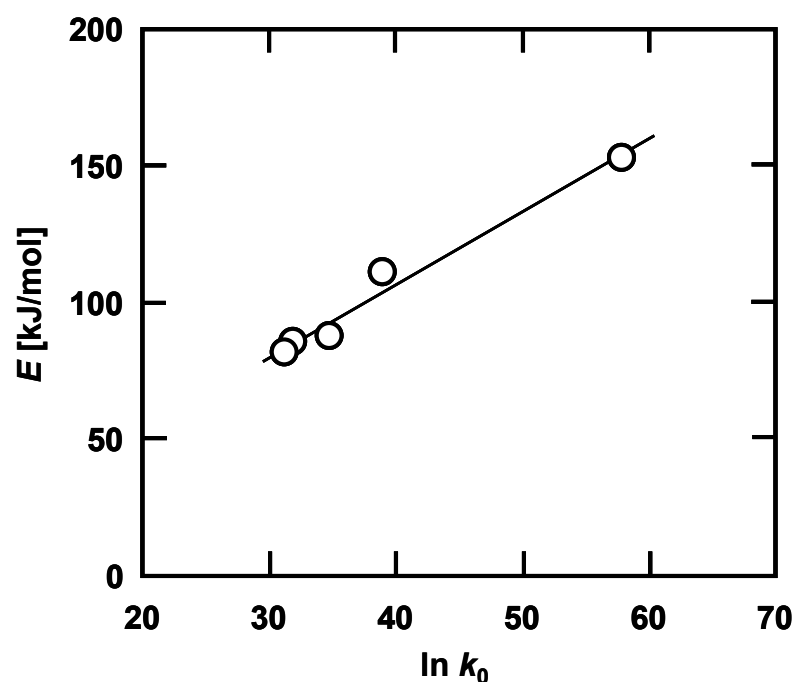

Fig. 5. Relationship between the apparent activation energy, $E$, and the logarithm of the frequency factor, $k_{0}$, for the rate constant of the Weibull model. The $k_{0}$ value is in units of $\mathrm{h}^{-1}$.

\subsection{Comparison between ascorbic acid}

\section{and octanoyl ascorbate for the catechin} degradation in aqueous solution

Chen et al. reported that ascorbic acid stabilized green tea catechins [12]. Further, apparent first order reaction rate of total catechins, such as (-)-epicatechin, (-)-epicatechin gallate, (-)-epigallocatechin and (-)-epigallocatechin gallate, in green tea with ascorbic acid was compared with that without it [14]. (+)-Catechin solution, not green tea extracts, was selected as a simple system to investigate antioxidative property of acyl ascorbate against a water-soluble and unstable compound in aqueous solution. Figure 6 shows the transient changes at $60^{\circ} \mathrm{C}$ and $\mathrm{pH} 6.0$ in the fractions of remaining catechin in the aqueous solution with ascorbic acid and octanoyl ascorbate at the concentrations of $0.001,0.005,0.01,0.1$, 1, 2 and $5 \mathrm{mmol} / \mathrm{L}$. The Weibull model was applied to these results. The $R^{2}$ values for $0.001,0.01,0.1$ and 1 $\mathrm{mmol} / \mathrm{L}$ of ascorbic acid were $0.886,0.947,0.973$ and 0.901 , and those for $0.001,0.005,0.01,0.1,1,2$ and 5 $\mathrm{mmol} / \mathrm{L}$ of octanoyl ascorbate were $0.986,0.983,0.938$, $0.956,0.945,0.938$ and 0.992 , respectively. The stability of catechin at every tested concentration of ascorbic acid was higher than that without the acid. For the catechin solution with ascorbic acid, it was observed that the stability was higher at the lower concentration of the acid. On the other hand, the stability of catechin with octanoyl ascorbate at concentrations less than $0.01 \mathrm{mmol} / \mathrm{L}$ was higher than that without the ascorbate, and that at concentrations greater than $0.1 \mathrm{mmol} / \mathrm{L}$ was lower. The

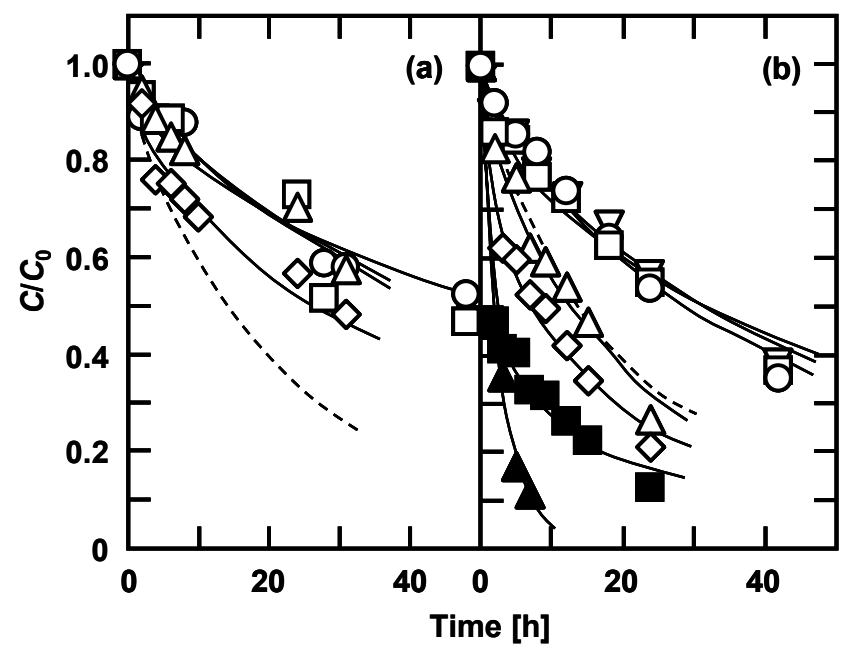

Fig. 6 Degradation processes at $60^{\circ} \mathrm{C}$ and $\mathrm{pH} 6.0$ of catechin with (a) ascorbic acid and (b) with octanoyl ascorbate at the concentration of $(\bigcirc)$ 0.001, $(\nabla) 0.005$, $(\square) 0.01,(\triangle) 0.1$, $(\diamond)$, ( $\square$ ) 2 and $(\boldsymbol{\Delta}) 5 \mathrm{mmol} / \mathrm{L}$. The degradation processes of catechin with $0.005,2$ and $5 \mathrm{mmol} / \mathrm{L}$ ascorbic acid were not measured. The solid and broken curves were calculated using the estimated kinetic parameters of the Weibull model for the degradation processes of catechin with and without the ascorbates, reapectively.

dependency of the estimated $k$ value on the concentration of ascorbic acid or octanoyl ascorbate is shown in Fig. 7. The adequacy of the Weibull model for the degradation processes of catechin with 0.001 and $1 \mathrm{mmol} / \mathrm{L}$ of ascorbic acid was a little low, but the dependency in the case of octanoyl ascorbate was obviously different from that for ascorbic acid. That is, octanoyl ascorbate showed its characteristic behavior as an antioxidative surfactant in aqueous solution. The antioxidative property of octanoyl ascorbate against catechin in an aqueous solution may be due to formation of the micelle for octanoyl ascorbate. The critical micelle concentration of octanoyl ascorbate in an aqueous solution was $1.24 \mathrm{mmol} / \mathrm{L}$ at 25 ${ }^{\circ} \mathrm{C}$ [7]. The partition of catechin from water to methyl octanoate, which was assumed to be the micelle phase formed by the octanoyl moiety of the ascorbate, was measured at $37^{\circ} \mathrm{C}$. The inset in Fig. 7 shows the relationship between the partition coefficient, $P$, and the initial concentration of catechin in the water phase. The $P$ value was higher at the higher catechin concentrations, though it was not more than 0.1 at $100 \mathrm{mmol} / \mathrm{L}$. As the $P$ value was very low, the partition of catechin to the micelle would not result in the apparent catechin decrease. Although the reason why octanoyl ascrobate acted on the catechin degradation as an antioxidant or a proxidant at the turning point of $0.1 \mathrm{mmol} / \mathrm{L}$ remains unclear, the for- 


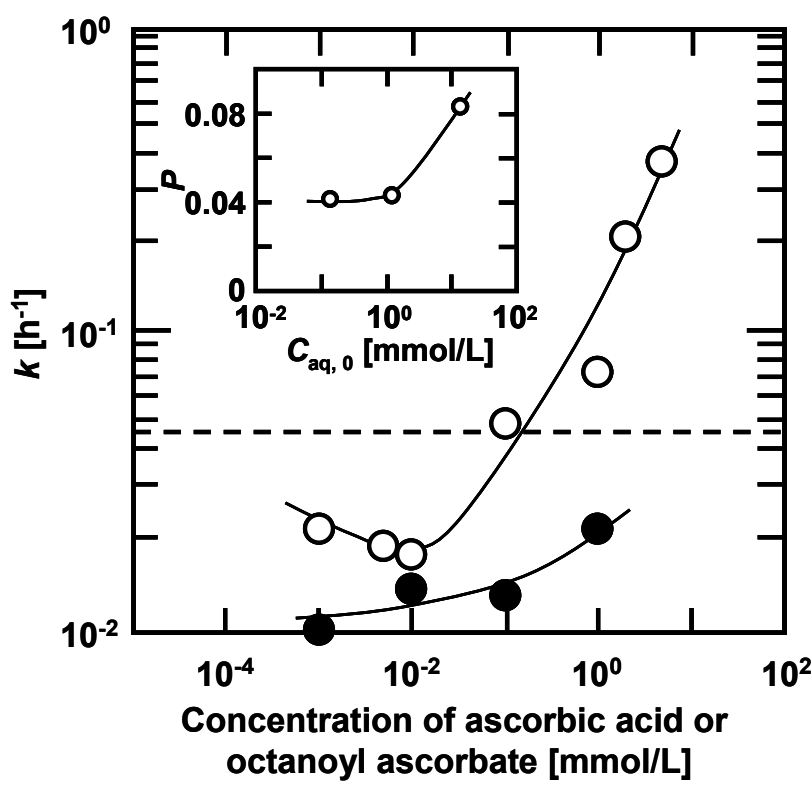

Fig. 7 Effect of the concentration of $(\bullet)$ ascorbic acid or $(\bigcirc)$ octanoyl ascorbate on the rate constant, $k$, at $60^{\circ} \mathrm{C}$ and $\mathrm{pH}$ 6.0. The broken line represents the $k$ value for the degradation of catechin with no additive at the corresponding conditions. The inset shows the relationship between the partition coefficient (methyl octanoate/water) at $37^{\circ} \mathrm{C}$ and the initial concentration of catechin. The solid curves were empirically drawn.

mation of the micelle for octanoyl ascorbate may prevent it from suppressing the oxidative degradation of catechin in an aqueous solution.

\subsection{Antioxidative property of octanoyl ascorbate against catechin in an aqueous solution at various temperatures}

Figure 8 shows the degradation processes of catechin with $0.001 \mathrm{mmol} / \mathrm{L}$ of octanoyl ascorbate at 37, 50, 60 and $70^{\circ} \mathrm{C}$ and $\mathrm{pH} 6.0$. The $R^{2}$ values on the Weibull model for $37,50,60$ and $70^{\circ} \mathrm{C}$ were $0.976,0.990,0.986$ and 0.851 , respectively. The application of the Weibull model to the degradation at $70^{\circ} \mathrm{C}$ seemed to be difficult. The octanoyl ascorbate retarded the degradation of catechin at each temperature, and the antioxidative effect of the ascorbate was observed over a wide temperature range. Especially, the degradation was strongly suppressed at $37^{\circ} \mathrm{C}$, and the fraction of remaining catechin was greater than 0.9 at 24 h. Figure 9 shows the relationship between the remaining fractions with and without the octanoyl ascorbate at 50,60 and $70^{\circ} \mathrm{C}$. Regardless of temperature, the plots were linear in Fig. $9\left(R^{2}=0.900\right)$, indicating that the antioxidative action of octanoyl ascorbate on catechin in an aqueous solution was independent of temperature.

\section{Conclusion}

It was kinetically indicated using the Weibull model that the stability of catechin in aqueous solution depended on the concentration, $\mathrm{pH}$ and temperature. Hold of the enthalpy-entropy compensation during the degradation of catechin suggested that each degradation at tested pHs essentially proceeded by the same mecha-

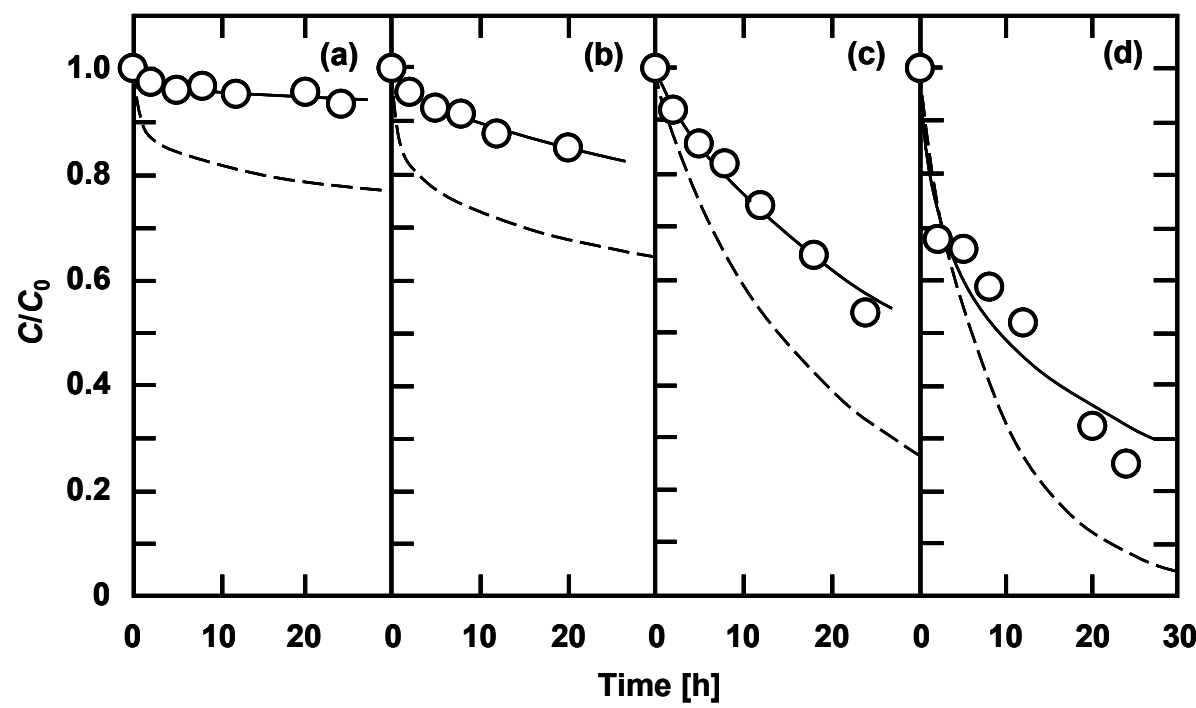

Fig. 8 Degradation processes of catechin with $0.001 \mathrm{mmol} / \mathrm{L}$ of octanoyl ascorbate at (a) $37^{\circ} \mathrm{C}$, (b) $50^{\circ} \mathrm{C}$, (c) $60^{\circ} \mathrm{C}$ and (d) $70^{\circ} \mathrm{C}$ and $\mathrm{pH} 6.0$. The solid and broken curves were calculated using the estimated kinetic parameters of the Weibull model for the degradation processes of catechin with and without octanoyl ascorbate, reapectively. 


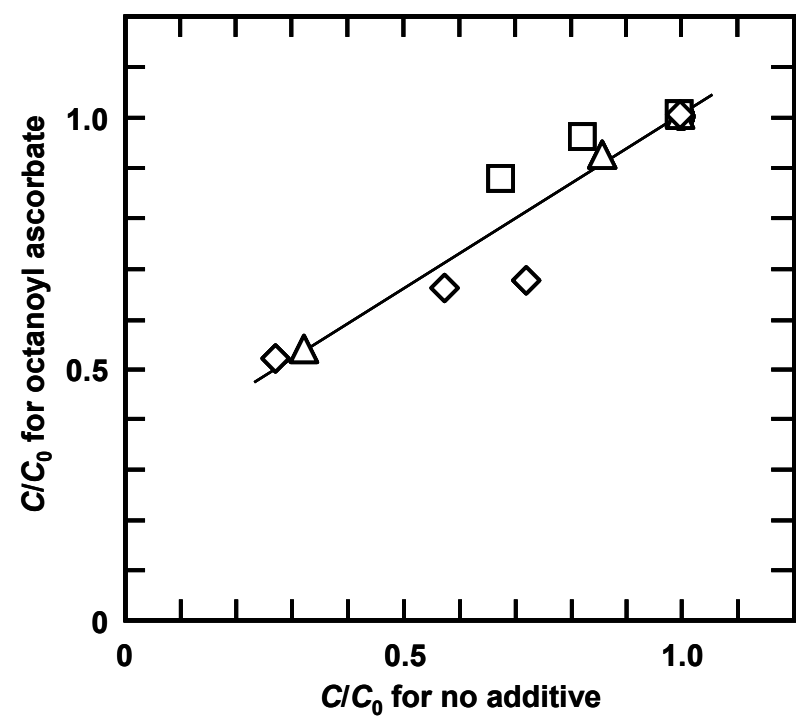

Fig. 9 Relationship between the remaining fractions, $C / C_{0}$, of catechin with and without octanoyl ascorbate at $(\square) 50^{\circ} \mathrm{C}$, $(\triangle) 60^{\circ} \mathrm{C}$ and $(\diamond) 70^{\circ} \mathrm{C}$ and $\mathrm{pH} 6.0$.

nism. The dependency of the rate constant for the degradation of catechin in the presence of octanoyl ascorbate on the concentration was different from that for the degradation with ascorbic acid, and octanoyl ascorbate acted as both antioxidant and proxidant depending on the concentration. The micelle formation of octanoyl ascorbate might prevent it from suppressing the oxidative degradation of catechin in an aqueous solution. Furthermore, it was shown that the antioxidative action of octanoyl ascorbate on catechin in aqueous solution was independent of temperature, but further research about the behavior of acyl ascorbate in aqueous solution is needed.

\section{Acknowledgments}

This work was supported by a Grant-in-Aid for Young Scientists (B) 19780106 from the Ministry of Education, Culture, Sports, Science and Technology (MEXT), Japan, and a research grant from the Japanese Society of Taste Technology, Japan.

\section{References}

1) C. Humeau, M. Girardin, D. Coulon, A. Miclo; Synthesis of 6-O-palmitoyl L-ascorbic acid catalyzed by Candida antarctica lipase. Biotechnol. Lett., 17, 1091-1094 (1995).

2) Y. Yan, U. T. Bornscheuer, R. D. Schmid; Lipase-catalyzed synthesis of vitamin C fatty acid esters. Biotechnol. Lett., 21, 1051-1054 (1999).
3) N. Miwa, H. Yamazaki; Potentiated susceptibility of ascites tumor to acyl derivatives of ascorbate caused by balanced hydrophobicity in the molecule. Exp.l Cell Biol., 54, 245-249 (1986).

4) N. Nagao, H. Matsubara, T. Yamanaka, T. Etoh, N. Miwa, H. Iwagaki, I. Saiki, S. Yamaoka, S. Itoh, E. Kokata; Functions of vitamin C for cells. (V) Mechanism for tumor infiltrationand metastasis-inhibitory effects of L-ascorbic acid (in Japanese). Vitamins, 70, 199-200 (1996).

5) Y. Watanabe, S. Adachi, K. Nakanishi, R. Matsuno Condensation of L-ascorbic acid and medium-chain fatty acids by immobilized lipase in acetonitrile with low water content. Food Sci. Technol. Res., 5, 188-192 (1999).

6) Y. Watanabe, K. Kuwabara, S. Adachi, K. Nakanishi, R. Matsuno; Production of saturated acyl L-ascorbate by immobilized lipase using a continuous stirred tank reactor, J. Agric. Food Chem., 51, 4628-4632 (2003).

7) Y. Watanabe, S. Adachi, T. Fujii, K. Nakanishi, R. Matsuno; Surface activity of 6-O-hexanoyl, octanoyl, decanoyl and dodecanoyl ascorbates, Jpn J. Food Eng., 2, 73-75 (2001).

8) Y. Watanabe, E. Ishido, X. Fang, S. Adachi, R. Matsuno; Oxidation kinetics of linoleic acid in the presence of saturated acyl L-ascorbate, J. Am. Oil Chem. Soc., 82, 389-392 (2005).

9) Y. Watanabe, X. Fang, Y. Minemoto, S. Adachi, R. Matsuno; Suppressive effect of saturated acyl L-ascorbate on the oxidation of linoleic acid encapsulated with maltodextrin or gum arabic by spray-drying. J. Agric. Food Chem., 50, 3984-3987 (2002).

10) S. W. Huang, E. N. Frankel; Antioxidant activity of tea catechins in different lipid systems. J. Agric. Food Chem., 45, 3033-3038 (1997).

11) T. Furuyashiki, H. Nagayasu, Y. Aoki, H. Bessho, T. Hashimoto, K. Kanazawa, H. Ashida; Tea catechin suppresses adipocyte differentiation accompanied by down-regulation of PPAR $\gamma 2$ and $\mathrm{C} / \mathrm{EBP} \alpha$ in 3T3-L1 cells. Biosci. Biotechnol. Biochem., 68, 2353-2359 (2004).

12) Z. Y. Chen, Q. Y. Zhu, Y. F. Wong, Z. Zhang, H. Y. Chung; Stabilizing effect of ascorbic acid on green tea catechins. J. Agric. Food Chem., 46, 2512-2516 (1998).

13) M. Friedman, H. S. Jürgens; Effect of $\mathrm{pH}$ on the stability of plant phenolic compounds. J. Agric. Food Chem., 48, 2101-2110 (2000).

14) Y. Komatsu, S. Suematsu, Y. Hisanobu, H. Saigo, R. Matsuda, K. Hara; Effects of $\mathrm{pH}$ and temperature on reaction kinetics of catechins in green tea infusion. Biosci. Biotechnol. Biochem., 57, 907-910 (1993).

15) R. Wang, W. Zhou, R. H. Wen; Kinetic study of the thermal stability of tea catechins in aqueous systems using a micro- 
wave reactor. J. Agric. Food Chem., 54, 5924-5932 (2006).

16) L. M. Cunha, F. A. R. Oliverira, J. C. Oliverira; Optimal experimental design for estimating the kinetic parameters of processes described by Weibull probability distribution function. J. Food Eng., 37, 175-191 (1998).

17) J. E. Leffer; The enthalpy-entropy relationship and its implications for organic chemistry. J. Org. Chem., 20, 1202-1231
(1955).

18) O. Exner; Concerning the isokinetic relationship. Nature, 201, 488-490 (1964).

19) L. Liu, Q. X. Guo; Isokinetic relationship, isoequilibrium relationship, and enthalpy-entropy compensation. Chem. Rev., 101, 673-695 (2001). 


\title{
アスコルビン酸またはオクタノイルアスコルビン酸存在下に 打ける水溶液中でのカテキンの分解動力学
}

\author{
渡邊義之 $^{1, \dagger}$ ，岡安辰徳 ${ }^{1}$, 井手之上花菜 ${ }^{1}$, 安達修二 ${ }^{2}$ \\ ${ }^{1}$ 近畿大学工学部生物化学工学科, ${ }^{2}$ 京都大学大学院農学研究科食品生物科学専攻
}

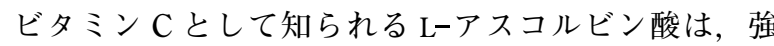
い還元能をもつため広く利用されている水溶性抗酸化 剮である。有機溶媒中でリパーゼの触媒作用を利用し たアスコルビン酸と脂肪酸との縮合反応により，6-Oアシルアスコルビン酸が合成されている．アシルアス コルビン酸は親水性基と親油性基を有する両親媒性の 抗酸化剤であり，抗腫瘍活性などを有するため有益な 食品添加物であるといえよう。著者らも，固定化リパー ゼを用いた回分および連続反応にて各種アシルアスコ ルビン酸を合成し，それらの界面活性剤特性や脂質に 対する抗酸化能を評価するとともに，脂質粉末化技術 への適用を検討した。しかしながら，アシルアスコル ビン酸の効果的な利用にはその水溶液中での挙動につ いての知見が必要であるにも関わらず，水溶液中での 抗酸化特性に関する検討はなされていない.一方，生 理的に有用な物質であるカテキンを含むほとんどの茶 飲料は，寒冷期間中はベンダー内で加熱保存され，そ のうえ好熱性嫌気性菌の胞子を死滅させるために高温 での熱処理が必要であるため，水溶液中での茶カテキ ンの安定性向上は重要な課題といえる. 本研究では, 水溶液中での $(+)$-カテキンの分解過程を様々な $\mathrm{pH}$ お よび温度下で測定した。そして，その分解過程を Weibull 式で表現し動力学パラメータを決定した。固定 化リパーゼを用いてアセトン中でアスコルビン酸とオ クタン酸を縮合させ，アシルアスコルビン酸の中では 比較的親水的なオクタノイルアスコルビン酸を合成し た。そして，アスコルビン酸またはオクタノイルアス コルビン酸を添加した場合の水溶液中でのカテキンの 分解動力学について検討した.

オクタノイルアスコルビン酸の合成には, Candida antarctica 由来の固定化リパーゼを用い，2-ブタノンお よび水による二相分配抽出にて精製した．所定量の力 テキン，アシルアスコルビン酸およびリン酸緩衝液 (pH5.0～7.5) を茶褐色バイアル瓶に入れ，所定温度 (37 $\left.\sim 70^{\circ} \mathrm{C}\right)$ の恒温水槽に浸し振盪させた. ODS カラム $(4.6$

(受付 2009 年 5 月 31 日，受理 2009 年 6 月 4 日)

1 个 739-2116 東広島市高屋うめの辺 1

2 于 606-8502 京都市左京区北白川追分町

† Fax: 082-434-7890, E-mail: wysyk@hiro.kindai.ac.jp $\mathrm{mm} \phi \times 250 \mathrm{~mm})$ および $\mathrm{UV}$ 検出器 $(280 \mathrm{~nm})$ を用いた HPLCにてカテキン残存量を測定した.

カテキン分解について動力学解析を行った結果, 力 テキン初濃度が高いほど Weibull 式の適合性が低かっ たが, 分解速度定数 $k$ および形状定数 $n$ がいずれも小 さかった. いずれの初濃度でも $n$ 值が 1 未満であった ため, 初期段階で分解が進み，徐々に分解速度が低く なることが示された。 これらの結果は，カテキン初濃 度が高いほど，カテキンの残存分率の低下が遅いこと を示している. また, $\mathrm{pH}$ 扎よび温度が低いほど $k$ 值が 低く，低温・低 $\mathrm{pH}$ でのカテキンの高い安定性が示され た。一方， $n$ 值には顕著な $\mathrm{pH}$ およよ゙温度依存性が認め られなかった。速度定数の温度依存性がArrhenius 式 に基づいて解析され，見かけの活性化エネルギーおよ び頻度因子を決定した結果，カテキン分解過程に打け るエンタルピーエントロピ補償の成立が示されたため, 異なる $\mathrm{pH}$ 下での分解が本質的に同じメカニズムで進行 したことが示唆された $\left(T_{\beta}=46.4^{\circ} \mathrm{C}\right)$. カテキン水溶液 へのアスコルビン酸添加によりその安定性が向上し, アスコルビン酸濃度が低いほど $k$ 值が低くなる傾向が 認められた。他方，オクタノイルアスコルビン酸を添 加した場合では，その濃度が $0.01 \mathrm{mmol} / \mathrm{L}$ 以下であれ ばカテキン分解が抑制され， $0.1 \mathrm{mmol} / \mathrm{L}$ 以上であれば 分解速度が高くなった.オクタノイルアスコルビン酸 の $25^{\circ} \mathrm{C}$ 水溶液中での臨界ミセル濃度が $1.24 \mathrm{mmol} / \mathrm{L} て ゙$ あるため，オクタノイルアスコルビン酸のこの特徴的 な挙動がミセル形成に起因するのではないかと考え, 水一オクタン酸メチル系でのカテキンの分配係数 $P$ を 測定した. カテキン濃度が高いほど $P$ 值は高かったが, いずれのカテキン濃度でも 0.1 未満であった. したがっ て, カテキンのミセル相への分配による見かけのカテ キン量の減少ではないことが確認された。しかし，才 クタノイルアスコルビン酸のミセル形成がカテキンの 不安定化に何らかの影響を与えているものと考えられ る. 異なる温度下に拈けるオクタノイルアスコルビン 酸添加時のカテキンの安定性を測定した結果，オクタ ノイルアスコルビン酸はいずれの温度でもカテキン分 解を抑制し，その抗酸化能は温度に依存しないで発現 されたことが示された。 